\title{
WHAT COÖPERATIVE SOCIETIES MAY ACCOMPLISH IN LOWERING FOOD DISTRIBUTION COSTS
}

\author{
By E. M. Tousley, \\ Editor Cosperation, and Secretary Right Relationship League, \\ Minneapolis, Minn.
}

The subject in hand would imply that the cost of food distribution is too high and that it may be lowered through the organization and proper operation of coöperative societies. In the treatment of this theme one can scarcely differentiate between the high cost of production and the high cost of distribution. The cost of the one, production, affects the cost of the other, inasmuch as the middleman system of distribution is carried on on a percentage basis of profit. It may therefore be necessary to analyze both phases to some extent.

We may begin by stating two self-evident facts: The farmer wants, and should get, on the average, higher prices for his products. Second, the consumer wants, and should be able to get, on the average, his products at lower prices. Here are two classes of people whose sole aim, so far as the subject under discussion is concerned, is to attain results diametrically opposed to each other. How may both classes secure the desired results? How may the farmer increase his income to a reasonable degree and the consumer at the same time be able to decrease his living expenses?

The answer is both simple and complicated. Coöperation, and coöperation alone, will do it. Coöperation, when properly inaugurated, does two things: First, it establishes a proper system of operation in both production and distribution and teaches efficiency in business principles, thus eliminating all the wastes of a lack of system. Second, it distributes justly the values created through its economic system.

\section{Two Grand Divisions}

In order to arrive at a proper basis for applying the economic and other principles in coöperation, it is necessary to take into consideration the two grand divisions entering into the cost of living, namely, production and distribution. Production is easily divisible 
into two subheads, namely, agricultural production and manufacfacturing.

Coöperation as applied to agricultural production and marketing, it may be said, has so far accomplished nothing in reduced prices to consumers. While there are no data whatever at hand to prove this assertion, we believe all will concede that no one has ever heard of lower retail prices to consumers by reason of the existence of coöperative societies among farmers. This is easily accounted for by the fact that the machinery of distribution is still in the hands of the so-called middlemen or those who are in the business solely for the purpose of making profits. There is no question but that in many instances the products of the farm have been greatly improved in quality by reason of coöperative organizations. We have only to point to the coöperative creameries of the middle West and to the coöperative citrus fruit societies of the Pacific coast. The improved quality of both of these products, as now offered to the consumer, is very marked indeed when compared with their quality twenty to twenty-five years ago. From the lesson thus taught, it may be assumed that when similar coöperative societies are formed for the production, grading, packing, and marketing of all farm produce, a like improvement may be made. And from this viewpoint, and the elimination of unnecessary waste in raising, preparing for market, and shipping, our great body of farmers may materially increase their income.

While such a result is desirable, we would still be confronted with the fact that the price to the consumer has increased rather than diminished. Whether or not the improved quality equalizes or more than makes up for the increase, is beside the mark. It is necessary that the agricultural producing end shall be efficiently organized into such coöperative societies, however, as a foundation for the eventual elimination of the present wastes of distribution.

As I am writing this article two dispatches in the daily papers demonstrate the enormous waste of the lack of system in farming, combined or added to which is that of the inefficient, extravagant, and improvident system of distribution, causing total dissipation of value to the farmer and increased cost to the consumer frequently to the extent of hunger. One item comes from New Haven, Conn., stating: "Nature's bounty in the flood of late peaches in orchards here is so generous that the fruit is being fed to hogs and cattle. 
Many growers will let peaches waste on the trees and on the ground. The best fruit ever seen here is offered at fifty cents a bushel at the orchards."

The other dispatch comes from Mankato, Minn., and says: "For the want of a market, fruit growers of this and adjoining counties are allowing tens of thousands of bushels of the finest kind of fall and winter apples ever raised in this state to rot on the ground under the trees or are feeding them to their hogs. Prices offered do not warrant farmers taking the time and trouble to market the apples, and they can be had almost for the asking."

Such a state of affairs, if true, shows criminal neglect or lack of organization and system, when there are millions of consumers within a radius of one to two hundred miles from these orchards, and a large majority of such consumers are financially unable to buy the fruit because of its high price.

\section{Machinery of Distribution}

Thinking men everywhere are beginning seriously to consider the problem of food distribution, by reason of the trend of population to the large cities in recent years. City people are apt to think only of their own ills in relation to the high cost of living, without taking into proper consideration the causes of those ills. The problem of economic living in cities is irrevocably tied up with better farming, better rural conditions generally, and proper and efficient systems of transportation and distribution.

This question divides itself into four general heads:

First. Marketing of agricultural products at primary points.

Second. Transportation.

Third. Wholesaling.

Fourth. Retailing.

These four general heads make up the entire machinery of distribution. If betterments are to be made and the cost of living of city consumers reduced, an exhaustive analysis of conditions and systems by which these different steps in distribution are now carried on is necessary. 


\section{Marketing of Agricultural Products at Primary Points}

While in Washington recently I had the pleasure of meeting Dr. Henry Charles Taylor, professor of agricultural economics, University of Wisconsin. I mentioned to him the necessity of organization for the improvement of marketing farm products at primary points. He asked me to write him on my return home, concerning the subject, which I did. I quote from that letter on the subject of "Standardization of Farm Products for Advantageous Marketing," as follows:

I think you realize the fact that no large organizations of consumers can be organized and operated in the cities with a high degree of success until such organizations can know exactly where to order this, that and the other farm product in accordance with some uniform standard.

Some authority in each state, or better still some federal authority, should establish and describe a standard for farm products.

After a standard has been fixed by some proper authority, the only way to teach the farmers to put the system into practical use is by organization for the raising of standardized products in various communities or by dividing a community into different sections, letting each section devote its principal attention to the raising of a certain product, always keeping the standard of such product in mind. By the right kind of organization the farmers' association can hire its expert to grade the various products brought to its warehouse and see that packages of the right shape, size and standard are used, properly packed and properly marked, and then see that the goods are shipped to a market which is not already over-stocked.

By the inauguration of such a system, in the opinion of the writer, the farmers could add to their annual income at least 10 per cent, and when a sufficient number of consumers' organizations in the cities are formed to absorb the standard product a like saving can be made by the consumers, thus benefiting both producer and consumer to this extent, and possibly much more. Until such standardization is effected the present waste will continue.

\section{Consumers' Organizations}

The next step in eliminating waste, in cutting out the unnecessary profits of the middleman system, and in inaugurating the corperative system, is that of forming coöperative societies of consumers in all large cities and towns. So far as America is concerned, the opposers of the coöperative movement have repeatedly asserted, and still maintain, that this is impossible; and yet we have only to point to the coöperative movement of Great Britain and many other foreign countries to prove that these assertions of the opposers of coöp- 
eration are absolutely untrue. Figures are at hand to prove that all the large cities of Great Britain have had flourishing retail coöperative societies operating thousands of stores for the last thirty to sixty years. During the last decade the sphere of activity of these coöperators has been extended to 742,485 new consumers, which is an increase of nearly 60 per cent. There are nearly 2,000 of these retail societies. In 1901 each society had, on an average, 1,204 members, while in 1910 the average number had increased to 1,716 . In fact, as nearly as can be estimated, practically one-third of the population of England and Scotland are coöperators, and one-third of the commercial business of those countries is conducted on the coöperative basis. And the best of it all is that the increase is steady and continuous from decade to decade.

In America a splendid start has been made. On the Pacific coast there is a movement containing a large number of coöperative stores in cities and towns. In the middle Northwest is the movement of the Right Relationship League, which, in less than eight years time, has organized over 150 coöperative stores. It is true that most of the successful coöperative stores in this country at the present time have been organized and are operating in smaller cities or rural villages. But the sentiment of the people in the larger cities is rapidly crystallizing around the thought that their people must organize coöperatively for self-protection.

\section{Bringing Producer and Consumer Together}

The organization and successful operation of coöperative societies in the cities, which shall include a large proportion of the population, are entirely feasible. Much space might be used in proving the fact. The requirements are a proper spirit among the people, an efficient system (and this is already at hand), and the constant education of the masses to coöperative principles. Dire necessity in many cases will force them to it.

Assuming that enough coöperative agricultural societies have been formed and are being successfully operated by the farmers, as set forth in the first half of this article, so that city organizations of consumers will know just where to secure their farm supplies of dependable quality, and assuming that the people of the cities have also organized large numbers of coöperative retail societies for the 
operation of stores for the proper service of their members-the next logical step is that of the connecting link-the wholesale.

\section{Wholesaling}

My readers are all more or less familiar with our systems of wholesaling. In country produce and live stock there are independent buyers at primary points who ship to commission men, or the produce is sold to the local country merchant. The commission men and country merchants sell to other commission men or jobbers in the cities, and the jobbers to the retailers, and so on to the consumer.

In manufactured articles the factory must buy its raw materials in the primary market; the goods pass through the manufacturing process; sometimes through the hands of several different factories with commission -brokers intervening; from the finishing mill to the big broker or jobber; from him to the local wholesaler; from him to the retail store; and from there to the homes of the consumers. Thus it will be seen that anywhere from three to six or more middlemen intervene between the actual producer and consumer.

The remedy is more easily stated than applied. All who have made any investigation whatever of the British system of coöperative production and distribution through coöperatively owned wholesale and retail stores know that the remedy lies in the assumption of responsibility, by the producers and consumers, of the ownership of the machinery of distribution, namely, the factory and the wholesale and retail stores.

Possibly the first step to be taken in bringing the producer and consumer together, increasing the income of the former and decreasing the cost to the latter, will be that of a coöperative commission warehouse and cold storage plant, which shall be the nucleus for a coöperative wholesale. Let the working capital of this commission concern, which is really the connecting link between producer and consumer, be jointly furnished by the farmer coöperative producing societies and the city coöperative consumers' societies; let all goods be bought and sold for cash and at the prevailing market rates; let there be no price-cutting. This will produce a surplus or socalled profit over and above operating expenses. This surplus or profit will then be available for division between the producers and 
consumers, one-half to each, as each has transacted business through the organization.

This connecting link, or federation, whatever it may be called at first, will naturally expand into a general wholesale society for the handling not only of farm produce but all manufactured products as well. Eventually it will also enter the manufacturing field, as have the coöperative wholesales of Great Britain and Europe.

\section{Some Figures}

The total business transacted by the retail coöperative societies of Great Britain in the year 1909 amounted to seven hundred millions of dollars, in round numbers, upon which there was a net saving of over 15 per cent, or approximately ninety-eight millions of dollars. The total trade done by all the wholesales (European), which amounted in 1900 to one hundred twenty-five million dollars, in 1910 reached over two hundred twenty-five millions; i.e., it was nearly doubled during the decade. In 1911 the total exceeded two hundred fifty million dollars.

The English Coöperative Wholesale Society contributed the largest share to this magnificent total. This society alone has to record since 1900 an increase in the amount of trade done of nearly $\$ 52,500,000$, or 65 per cent. Should this organization make equal progress during the second decade of the twentieth century, which we have every reason to expect, the turnover in 1920 will be about two hundred million dollars.

The profits of this large coöperative wholesale society during the first ten years of the century rose from $\$ 1,441,500$ to $\$ 2,314$,350 . The profits for 1911 reached the sum of nearly $\$ 2,900,000$, this being 2.07 per cent of the turnover.

What I am trying to show here is that when business is conducted coöperatively upon the same price level as that established and maintained by privately owned businesses, an enormous saving is made to the proprietors. When privately owned, this saving is called profit. When coöperatively owned, it is nothing more nor less than savings. These savings are then distributed to those who have created them or gathered them together by their trade or labor. Thus the profits or savings in coöperatively owned factories are handed down to the coöperatively owned wholesales and added 
to their profit accounts. The profits (savings) of the wholesales, augmented by those of the factories, are then handed down to the retail coonperative stores in proportion as the latter have patronized the former. The retail stores being owned coöperatively by the consumers, these accumulated profits or savings of the factories, wholesales and retails, are then distributed to the consumers in proportion to their trade, after paying operating expenses, which includes a reasonable rate of interest upon the capital invested by such consumers.

In Great Britain and in many countries on the continent these savings amount to anywhere from 10 to 25 per cent; that is to say, after all these different divisions of the business have been operated upon the same price level as are privately owned concerns, the record conclusively proves that, through the coöperative ownership and economic operation of these different branches of business, there is a total saving of an average of about 15 to 20 per cent. And thus is proved what coöperative societies may accomplish in lowering food and other distribution costs.

\section{Savings Enormous}

One who reads the figures of the British coöperative movement in percentages or by annual figures alone, can scarcely comprehend the enormous savings to the working people of that country. For instance, during the forty-eight years of the operation of the English Coöperative Wholesale Society, from 1864 to 1911 , the total profits or savings in that institution alone amounted to $\$ 36,030,380$, and the total profits or savings of the retail societies, of which only a portion of the returns are available, amounted, during the same period, to the inconceivable sum of $\$ 1,045,137,085$.

This great sum of money, after reserving enough to build magnificent temples of industry and palatial wholesale and retail premises, has been redistributed among the working people of Great Britain. The figures given denote a clear saving. In other words, since the year 1862, had the people of England and Scotland allowed their commercial business to be conducted as it has been conducted in America, by private traders, trusts, combines, etc., the common people, as the above figures show, would have had their living cost increased over one billion dollars, and probably much more, for the 
establishment of the coöperatives has unquestionably kept the general price level of the necessaries of life much lower than they would otherwise have been. And this wondrous record, the reader must be reminded, was made in competition with the productive genius of the whole world. The free trade system of Great Britain permits it.

Already in America the establishment and successful operation of thousands of coöperative agricultural associations and of the hundreds, at least, of successful coöperative retail stores, have proved that the principle is practically adaptable to American conditions. It still remains for us to complete the system. We must not stop with what has been accomplished, nor even hesitate. The people must go on acquiring the ownership of the machinery of distribution and develop the spirit and ability to operate it successfully.

Sentiment all over the country was never more ripe for the coöperative movement than at the present time, and the great task before those who are leaders is to concrete this sentiment into action and guide it along lines of genuine coöperation. Common corporations are springing up everywhere using the word "coöperation" or "coöperative" in their title, thus deceiving the people. Any corporation which allows a vote for each share of stock, or proxy voting, or which distributes its earnings upon capital invested rather than upon trade, is not coöperative; and when such organizations start under a coöperative title and the people are misled, it gives the true movement a setback from which it does not recover for years.

Many cities, including my own home, are agitating through improvement associations, women's clubs, and otherwise for municipal markets as a partial solution to the high cost of living. A large and influential group of Minneapolis citizens last winter demanded a bond issue of a half million dollars for the establishment of municipal markets. I do not claim to be much posted on the practical workings of municipal markets, but I take it that time will not turn backward in its flight and any considerable portion of the population of a large city get on the street cars with market baskets on their arms, ride several miles to market and carry home the produce in their baskets. Even if we grant that quite a large percentage of the people would do this, it doesn't touch the problem of high prices of manufactured goods, clothing, etc.

On the contrary, should the people of the city invest a half million dollars in a coöperative organization to operate coöperative 
stores, it would give a central store with a stock of one hundred thousand dollars and two hundred branch stores with a stock of two thousand dollars each, which could be placed under one modern, efficient, business management, and such a system would supply all parts of the city, serving all people alike with all the necessaries of life at a minimum cost. If such an organization could be formed, its bonds, representing perhaps its entire capital, could be paid off in fifteen to thirty years by a sinking fund made up of 10 to 20 per cent of the annual profits, the balance being distributed to the people. Thus would they be enabled to reduce their living expenses possibly 10 per cent through the operation of the retail stores alone. But ccöperative wholesaling and manufacturing would immediately follow as a matter of course, through the operations of which an additional 10 or 15 per cent could be saved.

The economy of operating business coöperatively when compared to competitive or privately-owned business, is well known. A single concrete illustration will suffice: A representative of the English and Scotch Coöperative Wholesale Societies has had an office in New York City for nearly forty years, purchasing American products for those societies. The volume of business handled by this office runs from six to ten million dollars per year, and the total expense of the British coöperators in buying this large volume of American products and having it laid down at their doors is something less than three-tenths of one per cent. Many similar instances of economy of operation might be cited. Many of the coopperative stores in the middle Northwest organized by the League are conducting their business at an expense rate of from six to ten per cent of the gross sales, which in many cases is only about half as great as that of privately-owned stores in the same communities should the latter figure the same salary for the proprietor and the same rate of interest on capital invested. How can it be otherwise when competitive marketing includes drummers, demonstration, samples, advertising by the manufacturer, downtown show rooms, jobbers, advertising by retailers, premiums, loss by bargain-sale baits, and the bookkeeping and unpaid accounts of the credit system, all of which coöperation can get along without?

The fundamental principles involved in true coöperation namely, one vote per member regardless of amount of investment, the limiting of the earning capacity of capital to the prevailing local rate of 
interest on money, and the distribution of the resulting profits or surplus savings over and above operating expenses in proportion to patronage, give strict justice to each participant and teach the people self-government. By reason of this education, coopperative producers and consumers are brought to see that through such a democratic business organization they are enabled to serve themselves most economically by eliminating all waste and unnecessary profits.

The cost of transportation by rail I leave to governmental regulation through the Interstate Commerce Commission. 